\title{
Telomerase activity, apoptosis and cell cycle progression in ataxia telangiectasia lymphocytes expressing TCLI
}

\author{
C Gabellini', A Antonelli', P Petrinelli ${ }^{2}$, A Biroccio', L Marcucci ${ }^{2}$, G Nigro ${ }^{3}$, G Russo ${ }^{4}$, G Zupi' and R Elli*,2 \\ 'Experimental Chemotherapy Laboratory, Regina Elena Cancer Institute, Rome, Italy; ${ }^{2}$ Cellular Biotechnology and Hematology Department, University 'La \\ Sapienza', Rome, Italy; ${ }^{3}$ Pediatric Institute, University 'La Sapienza', Rome, Italy; ${ }^{4}$ Istituto Dermopatico dell' Immacolata, Rome, Italy
}

Individuals affected by ataxia telangiectasia (AT) have a marked susceptibility to cancer. Ataxia telangiectasia cells, in addition to defects in cell cycle checkpoints, show dysfunction of apoptosis and of telomeres, which are both thought to have a role in the progression of malignancy. In I-5\% of patients with AT, clonal expansion of T lymphocytes carrying $t(|4 ;| 4)$ chromosomal translocation, deregulating TCLI gene(s), has been described. While it is known that these cells can progress with time to a frank leukaemia, the molecular pathway leading to tumorigenesis has not yet been fully investigated. In this study, we compared AT clonal cells, representing 88\% of the entire T lymphocytes (AT94-I) and expressing TCLI oncogene (ATM- ${ }^{-} \mathrm{TCLI}^{+}$), cell cycle progression to $\mathrm{T}$ lymphocytes of $\mathrm{AT}$ patients without $\mathrm{TCLI}$ expression $\left(\mathrm{ATM}^{-} \mathrm{TCLI}^{-}\right.$) by analysing their spontaneous apoptosis rate, spontaneous telomerase activity and telomere instability. We show that in $\mathrm{ATM}^{-} \mathrm{TCLI}^{+}$lymphocytes, apoptosis rate and cell cycle progression are restored back to a rate comparable with that observed in normal lymphocytes while telomere dysfunction is maintained.

British Journal of Cancer (2003) 89, I09I-1095. doi:I0.1038/sj.bjc.660 I 213 www.bjcancer.com

(c) 2003 Cancer Research UK

Keywords: ataxia telangiectasia; TCL I; telomere; apoptosis; cell cycle

Ataxia telangiectasia (AT) is an autosomal recessive disease characterised by progressive cerebellar degeneration, variable immunodeficiency, genomic instability and susceptibility to cancer, especially lymphoid malignancies. The product of ATM gene, which is mutated in individuals affected by AT, belongs to a well-conserved family of protein kinases. It is involved in the control of the cell cycle, in the processing of DNA damage and in the maintenance of genome integrity (caretaker gene) (Shiloh and Kastan, 2001). In particular, the Atm protein is homologous to Tellp, which is essential for telomere maintenance in Saccharomyces cerevisiae (Greenwell et al, 1995; Pandita, 2002), and may regulate the structure and the function of telomeres through a not yet fully understood mechanism; indeed, AT cells have an accelerated rate of telomere loss and show chromosomal end-to-end telomeric fusions/associations (tas), in spite of having normal telomerase activity (Pandita et al, 1995; Metcalfe et al, 1996). Furthermore, Atm might play a role in apoptosis as suggested by its involvement as a substrate of caspase 3 (Smith et al, 1999); however, different cell types that lack the ATM function show apoptotic behaviour not always consistent (Meyn, 1999; Bebb et al, 2001).

Tumours of the lymphoid system are very frequent in AT patients. Among them T-prolymphocytic leukaemia (T-PLL), a very rare lymphoid neoplasia in general population, is also quite

\footnotetext{
*Correspondence: Professor R Elli, Dipartimento di Biotecnologie Cellulari ed Ematologia, Policlinico Umberto I, Viale Regina Elena 324, 00 I6I Rome, Italy; E-mail: ell@ @bce.uniromal.it Received 19 March 2003; accepted 25 June 2003
}

often observed in AT patients (Taylor et al, 1996). These T-PLLs in ATs have been well characterised in the past by several groups including us, and are quite invariably preceded by a $\mathrm{T}$ cell clonal expansion identifiable cytogenetically to carry a $t(14 ; 14)$ $(\mathrm{q} 11 ; \mathrm{q} 32.1)$ translocation or an $\operatorname{inv}(14)(\mathrm{q} 11 ; \mathrm{q} 32.1)$ inversion or a $\mathrm{t}(\mathrm{X} ; 14)(\mathrm{q} 28 ; \mathrm{q} 32.1)$ translocation. With the time, usually years, these clonal cells are able to expand until they represent up to $90 \%$ of the circulating T lymphocytes and ultimately to evolve into an overt leukaemia. These chromosomal rearrangements, at molecular level, bring regulatory elements of the TCR $\alpha$ (located on 14q11) to a new position on $14 \mathrm{q} 32.1$ or Xq28 resulting in activation of usually silent genes in normal mature $\mathrm{T}$ cells. These genes belong to the TCL1 gene family: TCL1 and TCL1b are located on 14q32.1 and MTCP1 is on Xq28 (Stern et al, 1993; Virgilio et al, 1994; Pekarsky et al, 1999). Tcl1, Tcl1b and Mtcp1 identify a new family of proteins since they are practically identical, either by sequence or structure, and are usually absent in mature normal circulating $\mathrm{T}$ cells. The consequences of TCL1 expression are due to its binding to the serine/threonine kinase Akt (also called protein kinase B, PKB), by increasing kinase activity and enhancing Akt nuclear translocation (Laine et al, 2000; Pekarsky et al, 2000). Furthermore, TCL1 family gene members have oncogenic ability, as clearly demonstrated by four different transgenic animal models in which overexpression of these genes, in either T or B cells, causes T-PLL, B-chronic lymphocytic leukaemia (B-CLL) or mature B-cell lymphoma (Gritti et al, 1998; Virgilio et al, 1998; Bichi et al, 2002; Hoyer et al, 2002).

We previously described a large nonleukaemic clone carrying the chromosomal tandem translocation $\mathrm{t}(14 ; 14)(\mathrm{q} 11 ; \mathrm{q} 32)$ in an 
AT patient (AT94-1), who, at present, has not yet shown any sign of malignancy. The clonal cells are characterised by the overexpression of the TCL1 oncogene (Narducci et al, 1995), a high rate of spontaneous chromosome instability (especially of tas) (Petrinelli et al, 2001) and hypersensitivity to the topoisomerase II inhibitor VP16 (Petrinelli et al, 1996). These clonal cells represent a very useful tool to study the biological consequences of TCL1 overexpression in the context of ATM deficiency since they are not hampered by ectopic transfection. In this study, we report that in this AT cell clone, even when VP16-damaged, the apoptosis rate and the cell cycle progression are restored back to a rate comparable with that observed in normal lymphocytes while telomere dysfunction is maintained.

\section{MATERIALS AND METHODS}

\section{Lymphocyte cultures}

Peripheral blood samples were obtained from the AT94-1 patient, from six normal controls and from two AT controls (AT95-1 and AT95-2). AT94-1 and AT95-2 were reported as AT22RM and AT28RM, respectively, by Gilad et al (1996).

To evaluate the spontaneous rate of tas, chromosome preparations were performed by standard method, and analysed on Gbanded metaphases by two independent observers.

To evaluate telomerase activity, telomere length, cell cycle progression and apoptosis, blood was defibrinated and mononuclear cells isolated by centrifugation on a layer of histopaque 1077 (Sigma Diagnostic, Milan, Italy). Purified lymphocytes $\left(1 \times 10^{6} \mathrm{ml}^{-1}\right)$ were incubated for $72 \mathrm{~h}$ in RPMI 1640 (Sigma) supplemented with $10 \%$ fetal calf serum, penicillin, streptomycin and PHA $\left(5 \mu \mathrm{g} \mathrm{ml}^{-1}\right)$. To evaluate the effects of the topoisomeraseII inhibitor VP16 on cell cycle and apoptosis, VP16 (final concentration $0.1 \mu \mathrm{g} \mathrm{ml}^{-1}$ ) was added to purified lymphocyte cultures $48 \mathrm{~h}$ before harvesting (Petrinelli et al, 1996).

\section{Telomerase activity and telomere length}

Telomerase activity was measured with the PCR-based TRAP (telomeric repeat amplification protocol) kit (Intergen Company, Oxford, UK) according to the manufacturer's instructions. To define the sensitivity of the method and the semiquantitative relationship between protein concentration and ladder band intensity, different amounts of protein extract (from 0.1 to $2 \mu \mathrm{g}$ ) were used for each purified lymphocyte culture and for all assays. The appropriate protein concentration to produce a linear response was $1 \mu \mathrm{g}$ of the total protein. In all cases, reaction products were amplified in the presence of a $36 \mathrm{bp}$ internal TRAP assay standard (ITAS), and each extract was tested for RNAse sensitivity, incubating samples with $20 \mathrm{ng}$ RNAse (Sigma) for $30 \mathrm{~min}$ at $37^{\circ} \mathrm{C}$ before extension/amplification reaction. Telomeric repeat amplification protocol assay included a sample without cell lysate as negative control and a positive control sample provided by the kit. Telomere length was evaluated by Southern blot as previously reported (Biroccio et al, 2002). Briefly, total DNA was isolated using standard procedure. For each sample, $15 \mu \mathrm{g}$ of DNA were digested with $40 \mathrm{U}$ of Hinf1 and electrophoresed on $0.8 \%$ agarose gel. DNA was denatured, neutralised, transferred to a nylon membrane (Hybond $\mathrm{N}$, Amersham International, Buckinghamshire, UK) and cross-linked with ultraviolet light. The membrane was hybridized with $5^{\prime}$-end $\left[\gamma^{32} \mathrm{P}\right]$ deoxyadenosine triphosphate-labelled telomeric oligonucleotide probe (TTAGGG) at $42^{\circ} \mathrm{C}$ for $4 \mathrm{~h}$ in a rapid hybridization buffer (QuikHyb Hybridization Solution, Stratagene, La Jolla, USA). After washing, the filters were autoradiographed (Hyperfilm-MP; Amersham) with an intensifying screen at $-80^{\circ} \mathrm{C}$ for $24 \mathrm{~h}$. The autoradiographs were scanned and the mean telomere length was calculated as reported by Harley et al (1990).

\section{Cell cycle analysis and detection of apoptosis}

The percentage of cells in the different phases of cell cycle was determined by evaluating DNA content. Treated and untreated cells $\left(2 \times 10^{6}\right)$ were collected at $72 \mathrm{~h}$ of culture, washed with PBS and fixed with $2 \mathrm{ml}$ of $70 \%$ ethanol. After washing twice in PBS, the cells were stained with a solution containing $50 \mu \mathrm{g} \mathrm{ml}^{-1}$ propidium iodide (PI) and $75 \mathrm{kU} / \mathrm{ml}$ RNAse in PBS for $30 \mathrm{~min}$ at room temperature. A total of 20000 events per sample were acquired by FACSCalibur (Becton-Dickinson) using a doublet discrimination module (DDM). The percentages of cell cycle distribution and subG1 apoptotic cells were calculated on linear PI histograms using the mathematical software ModFit. Apoptotic cells were also detected by using the APO-BRDU ${ }^{\mathrm{TM}}$ kit (BioSource International, Camarillo, California), a terminal deoxynucleotide transferase (TdT)-mediated Br-dUTP nick-end labelling (TUNEL), according to the manufacturer's instruction. Briefly, $2 \times 10^{6}$ of treated and untreated cells were collected at $72 \mathrm{~h}$ of culture, washed with PBS and fixed with $2 \mathrm{ml}$ of $70 \%$ ethanol. The fragmented DNA was revealed incubating the samples with the labelling reaction mix for $1 \mathrm{~h}$ at $37^{\circ} \mathrm{C}$; the BrdU-labelled cells were then stained with a fluorescein-labelled anti-BrdU antibody solution for $30 \mathrm{~min}$ at room temperature, in the dark. To determine DNA content, a PI/ RNAse solution was added to FITC-labelled cells and incubated for $30 \mathrm{~min}$ at room temperature, in the dark.

\section{Statistical analysis}

Statistical evaluation of apoptosis and cell cycle data was performed by Student's $t$-test.

\section{RESULTS}

\section{Telomerase activity and telomere length in AT} lymphocytes expressing TCL1

In order to study the correlation between chromosome end-to-end fusions (tas) and telomere metabolism, we evaluated telomerase activity and telomere length in PHA-stimulated lymphocytes characterised by different tas frequency. The cells used were: AT lymphocytes with TCL1 expression (AT94-1), which are characterised by a high frequency of spontaneous tas (Table 1); Ataxia telangiectasia lymphocytes without TCL1 expression (AT95-1 and AT95-2) showing sporadic tas; and normal lymphocytes, with no detectable tas. The telomerase activity was evaluated by a semiquantitative TRAP assay. Figure 1 shows that the loss of the ATM function alone determines a marked decrease in telomerase activity (see AT95-1 and AT95-2), while the expression of TCL1, characteristic of AT94-1 clonal lymphocytes, is able to restore telomerase activity up to the level observed in normal lymphocytes. The internal telomerase assay standard (ITAS) was amplified to the same extent in all cell cultures, excluding the presence of Taq polymerase inhibitors in AT lymphocytes without TCL1 expression.

We then tried to determine whether the increase of telomerase activity observed in AT cells expressing TCL1 was associated with reduced telomere shortening. Terminal restriction fragments (TRFs) were obtained by Southern blotting in the same cells analysed by TRAP assay (Table 2). TRFs in AT lymphocytes without TCL1 expression were shorter (mean value $13.1 \mathrm{~kb}$ ) than in normal lymphocytes (mean value $15.6 \mathrm{~kb}$ ). AT94-1 lymphocytes (expressing TCL1) showed a telomere length range superimposable to that observed in AT lymphocytes not expressing TCL1, although these two kinds of AT cells have different telomerase activity and different tas frequency. 
Table I Spontaneous telomeric associations (tas) in metaphases with $\mathrm{t}(14 ; 14)$ from AT94-I lymphocytes

\begin{tabular}{|c|c|c|c|}
\hline Date & $\begin{array}{l}\text { No. cells } \\
\text { analysed }\end{array}$ & $\begin{array}{l}\text { Metaphases } \\
\text { with tas }\end{array}$ & $\begin{array}{l}\text { Metaphases with } \\
\text { subclonal } \\
\text { rearrangements }\end{array}$ \\
\hline 2001 & 52 & 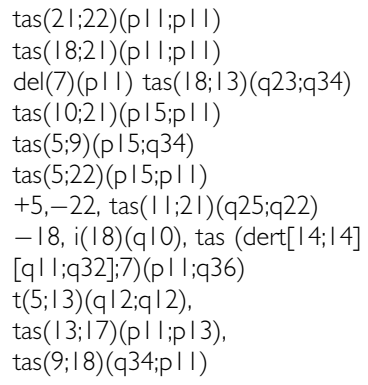 & $\begin{array}{l}-22,+\operatorname{mar} \mid[2] \\
\mathrm{i}(2 \mathrm{I})(\mathrm{q} \mid 0)[5] \\
\mathrm{i}(2 \mathrm{I})(\mathrm{q} \mid 0), \\
\operatorname{tas}(|0 ;| 5)(\mathrm{p}|5 ; \mathrm{p}| \mathrm{I}) \\
\mathrm{i}(2 \mathrm{I})(\mathrm{q} \mid 0), \\
\operatorname{tas}(\mathrm{I} \mid \mathrm{|})(\mathrm{p} 36 ; \mathrm{p} \mid \mathrm{I}) \\
+6, \mathrm{i}(2 \mathrm{l})(\mathrm{q} \mid 0)\end{array}$ \\
\hline 2002 & 56 & $\begin{array}{l}\operatorname{tas}(4 ; 2 \mid)(p|6 ; p| I) \\
\operatorname{tas}(5 ; 6)(p \mid 5 ; p 25) \\
\operatorname{tas}(21 ; 21)(p \mid I ; q 22) \\
\operatorname{tas}(4 ; \mid 3)(p \mid 6 ; q 34) \\
+X, \operatorname{tas}(\mid 2 ; 18)(q 24 ; p \mid I) \\
\operatorname{tas}(21 ; 22)(p|1 ; q| 3) \\
\operatorname{tas}(2 ; \mid 8)(q 37 ; p \mid I) \\
\operatorname{tas}(5 ; 15)(p|5 ; p| I) \\
\operatorname{tas}(4 ; 21)(p \mid 6 ; q 22)\end{array}$ & $\begin{array}{l}-22,+\operatorname{marl}[2] \\
\mathrm{i}(2 \mathrm{I})(\mathrm{q} \mid 0)[3] \\
\mathrm{i}(2 \mathrm{l})(\mathrm{q} \mid 0), \\
\operatorname{inv}(3)(\mathrm{p} 2|\mathrm{q}| \mathrm{I})\end{array}$ \\
\hline
\end{tabular}

The metaphases with the $\mathrm{t}(14 ; 14)$ rearrangement represented 80 and $73 \%$ of total AT94-I lymphocytes, respectively, in 200 I and in 2002. Metaphases with sporadic nonclonal rearrangements were also observed (data not shown). The cytogenetic follow-up of AT94-I from 1995 to 2000 has been previously reported (Petrinelli et al, 200I).

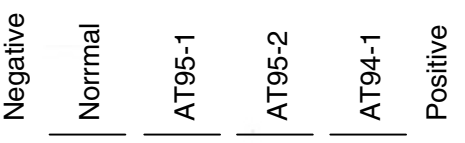

ITAS

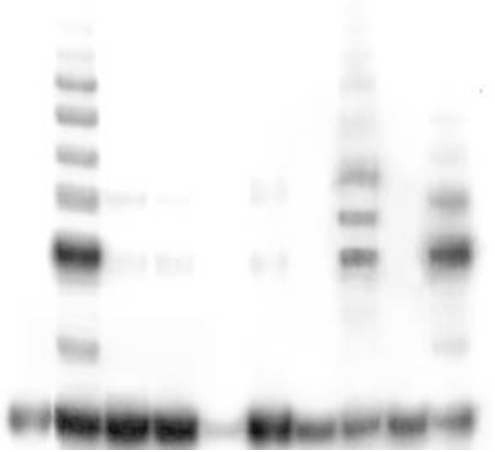

RNAse --+-+-+-+

Figure I TRAP assay to evaluate the effect of ATM status and TCLI expression on telomerase activity in human PHA-stimulated lymphocytes. From left to right: a negative control; a sample of normal lymphocytes; two samples of AT lymphocytes (AT95-I, AT95-2); a sample of AT lymphocytes expressing TCLI (AT94-I); a positive control.

\section{Decreased apoptosis and restoration of cell cycle progression in AT lymphocytes expressing TCL1}

In order to ascertain whether the differences in telomere metabolism in cells that have lost the ATM function are due to different rates of proliferation and/or apoptosis, we analysed these
Table 2 Terminal restriction fragments calculated by Southern blot analysis of normal, AT and TCLI espressing AT lymphocytes hybridized with the telomeric repeats (TTAGG)

\begin{tabular}{lcc}
\hline & \multicolumn{2}{c}{ Telomere length (kbp) } \\
\cline { 2 - 3 } Cells & Min & Max \\
\hline $\mathrm{AT}^{+} \mathrm{TCLI} I^{-}$ & $12.2 \pm 0.2$ & $19.0 \pm 0.2$ \\
$\mathrm{AT}^{-} \mathrm{TCLI} I^{-}$ & $10.6 \pm 0.2$ & $15.6 \pm 0.1$ \\
$\mathrm{AT}^{-} \mathrm{TCLI} I^{+}$ & $10.5 \pm 0.2$ & $15.7 \pm 0.1$ \\
\hline
\end{tabular}

The results are the mean values of three experiments.

A Normal lymphocytes
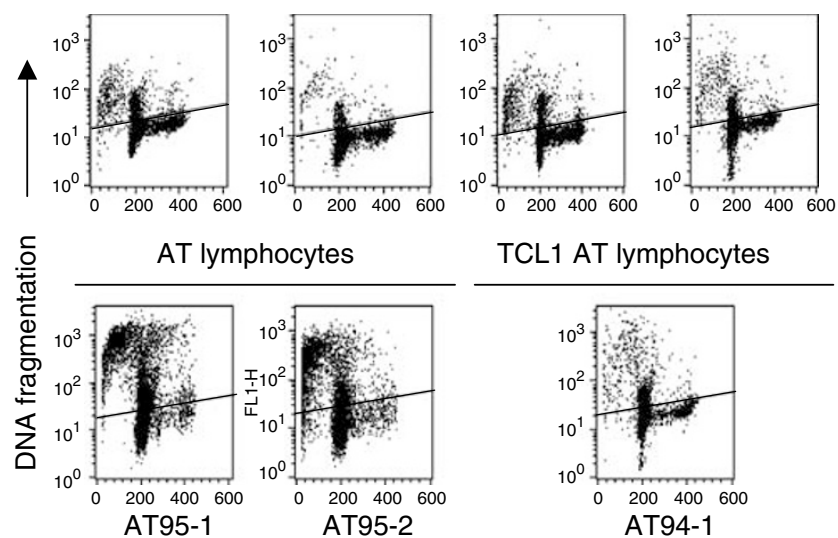

TCL1 AT lymphocytes

DNA content

B

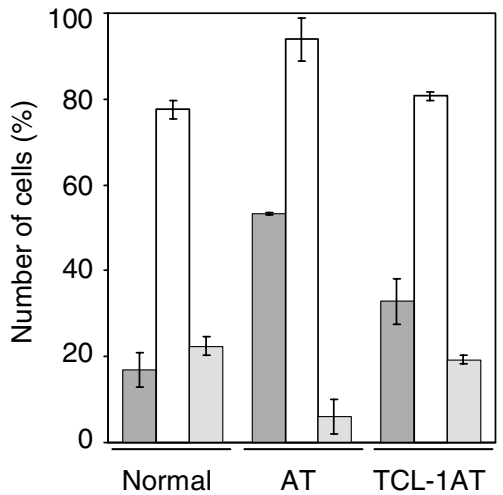

Figure 2 Evaluation of apoptosis and DNA content of different types of lymphocytes. (A) Results of a representative TUNEL assay performed on four samples of normal lymphocytes, two of AT lymphocytes (AT95-I and AT95-2) and one of TCLI expressing AT lymphocytes (AT94-I). (B) TUNEL-positive cell percentage (dark grey columns), cell percentage in the $G_{0} / G_{1}$ phase (white columns) and in the $S-G_{2} / M$ phase (grey columns) of cell cycle. Each experiment was performed at least three times.

two features comparing AT lymphocytes with and without TCL1 expression. A flow cytometric TUNEL assay, performed in a biparametric analysis with DNA content (Figure 2A), was carried out in four different samples of normal lymphocytes, in two AT lymphocytes (AT95-1, AT95-2) and in AT94-1 lymphocytes. Each sample was analysed at least three times. Figure $2 \mathrm{~B}$ shows the mean values of apoptotic cells (dark grey columns) together with the mean percentages of cells in the different phases of cell cycle $\left(\mathrm{G}_{0} /\right.$ $\mathrm{G}_{1}$, white columns; $S-\mathrm{G}_{2} / \mathrm{M}$, grey columns). Ataxia telangiectasia lymphocytes without TCL1 expression (see AT) were characterized 
Table 3 Effect of TCLI expression on apoptosis and on cell cycle in AT lymphocytes after treatment with VPI6

\begin{tabular}{lcc}
\hline Cells & $\mathbf{S}-\mathbf{G}_{\mathbf{2}} / \mathbf{M}$ accumulation & Apoptosis increase \\
\hline $\mathrm{AT}^{+} \mathrm{TCLI}^{-}$ & $2.01 \pm 0.14$ & $1.65 \pm 0.08$ \\
$\mathrm{AT}^{-} \mathrm{TCLI}^{-}$ & $1.24 \pm 0.13$ & $0.90 \pm 0.06$ \\
$\mathrm{AT}^{-} \mathrm{TCLI}^{+}$ & $2.33 \pm 0.2$ & $1.81 \pm 0.39$ \\
\hline
\end{tabular}

Data are presented as a ratio between the percentages of treated vs untreated cells, respectively, in $\mathrm{S}-\mathrm{G}_{2} / \mathrm{M}$ compartment and in apoptosis. Values are the mean and s.e. of five experiments for $\mathrm{AT}^{+} \mathrm{TCLI}^{-}$(normal control), five experiments for $\mathrm{AT}^{-}$ $\mathrm{TCLI}^{-}$(AT control) and three experiments for $\mathrm{AT}^{-} \mathrm{TCLI}^{+}$(AT94-I).

by a significant $(P<0.01)$ spontaneous activation of the apoptotic programme $(53.3 \pm 0.4)$ if compared with normal lymphocytes $(17.0 \pm 2.1)$ and showed a strong proliferative block in the $G_{0} / G_{1}$ phase. The expression of TCL1 in AT cells determined a decrease of the apoptotic rate $(32.9 \pm 5.3)$ and was able to restore a 'normal like' cell cycle by driving the AT cells in the $S$ phase. In fact, the differences in the percentage of cells in $G_{0} / G_{1}$ and $S-G_{2} / M$ phases between normal and AT94-1 lymphocytes were not significant $(P>0.05)$.

We next evaluated the same parameters in the same cells after DNA damage induction by VP16 treatment (Table 3). As expected, in normal lymphocytes $\left(\mathrm{AT}^{+} \mathrm{TCL}^{-}\right)$VP16 treatment induced a significant $(P<0.01)$ increase of the percentage of cells in $S+\mathrm{G}_{2} / \mathrm{M}$ compartement and in apoptosis, while we observed no significant $(P>0.05)$ change for both parameters in control AT lymphocytes $\left(\mathrm{AT}^{-} \mathrm{TCL}^{-}\right)$. On the contrary, in AT lymphocytes expressing TCL1 $\left(\mathrm{AT}^{-} \mathrm{TCL}^{+}\right)$VP16 treatment determined an increase of apoptosis rate and of percentage of cells in the $S-G_{2} / M$ compartment comparable to those observed in normal lymphocytes.

\section{DISCUSSION}

In this study, we demonstrated that AT94-1 T lymphocytes have lost the general growth disadvantage caused by the lack of the $A T M$ function. The dramatic reduction of cells in the $\mathrm{S}$ and $\mathrm{G}_{2}$ phases of the cell cycle, characteristic of nonclonal AT lymphocytes, was not observed in AT94-1 lymphocytes since these cells showed a cell cycle distribution similar to that observed in normal cells. Furthermore, our results suggest that TCL1 expression is correlated with a reduced apoptotic rate in the apoptotic-prone $\mathrm{ATM}^{-}$cells (Duchaud et al, 1996). The differences in cell proliferation and survival were also evident in cells treated with VP16, a topoisomerase II inhibitor that acts at premitotic phase and induces apoptosis in mitogen-activated $\mathrm{T}$ lymphocytes (Sinkule, 1984; Ferraro et al, 2000). Indeed, when damaged with VP16, only $\mathrm{ATM}^{-} \mathrm{TCL}^{+}{ }^{+}$lymphocytes were able to show an increase, both in apoptosis rate and in percentage of cells in the S$\mathrm{G}_{2} / \mathrm{M}$ compartment, similar to that observed in VP16-treated normal lymphocytes $\left(\mathrm{ATM}^{+} \mathrm{TCL}^{-}\right)$.

We also showed that AT94-1 cells exhibited telomere shortening, increased telomerase activity and chromosomal instability, especially telomeric end-to-end fusions (tas). The coexistence of telomere instability and telomerase activation in AT94-1 cells can be explained by taking into account that telomerase activity does not necessarily result in telomere elongation, in agreement with previous studies (Metcalfe et al, 1996). Indeed, telomerase might have a dual function for telomeres, protection and elongation, and could therefore promote cell survival and growth, independently of net telomere elongation (Zhu et al, 1999; Blasco, 2002). We also observed that endogenous expression of telomerase in AT94-1 cells is unable to correct the cytogenetic phenotype of telomere instability (i.e. tas). In agreement with this, Wood et al (2001) showed that the ectopical expression of the human telomerase gene hTERT in AT fibroblasts does not correct the telomere end-association defect, despite maintaining/extending telomere length. Thus, tas frequency could be dependent on ATM loss, but is telomerase independent. In fact, as suggested by Pandita and Dhar (2000), ATM could be involved in telomere-mediated function through telomere-nuclear matrix interaction. Therefore, AT94-1 lymphocytes regain telomerase activity despite high frequency of tas, show low spontaneous apoptosis rate and restore cell cycle progression. It is then TCL1 expression that confers these advantages to $\mathrm{ATM}^{-}$cells. Even though we cannot exclude that other undetected genetic alterations might be present in the clonal cells, TCL1 seems to play an important role in these features. This idea is consistent with the observation that TCL1 is uniquely expressed in AT94-1 lymphocytes and not in other AT or normal T lymphocytes (Narducci et al, 1995, 2000) and that it has a proliferative and antiapoptotic role as demonstrated by recent biochemical findings and studies in animal models. More specifically, biochemical evidence demonstrates that Tcll acts in vivo as a coactivator of the Akt protein, enhancing its kinase activity and mediating its nuclear translocation (Pekarsky et al, 2000; Kunstle et al, 2002). Akt, in turn, has a central role in the regulation of several signalling pathways controlling cell survival and proliferation in $\mathrm{T}$ cells. Indeed, activated Akt enhances human telomerase activity through phosphorylation of the hTERT subunit (Kang et al, 1999), inhibits the proapoptotic factor Bad (Nicholson and Anderson, 2002) and, in $T$ lymphocytes, has a key role in $G_{1}-S$ phase progression through the regulation of $\mathrm{pRB}$ (retinoblastoma protein) phosphorylation (Brennan et al, 1997). The same pathway Akt/pRB/E2F is required also to protect activated peripheral $\mathrm{T}$ cells from bcl-2independent apoptosis (Lauder et al, 2001). The overexpression of this gene in $\mathrm{T}$ or $\mathrm{B}$ lymphocytes of transgenic mice induces, respectively, a T-PLL, B-CLL or mature B-cell lymphoma (Virgilio et al, 1998; Bichi et al, 2002; Hoyer et al, 2002). Interestingly, Fears et al (2002) reported that one cell line, derived from a relapse in a child with acute lymphatic leukaemia (ALL), showed TCL1 overexpression and a much higher rate of proliferation when compared to a previously established cell line from the same patient. The increase in TCL1 expression correlates with disease progression and more aggressive phenotype in this child.

In conclusion, clonal $\mathrm{T}$ cells carrying $\mathrm{t}(14 ; 14)$ chromosomal translocation and expressing TCL1 seem to be able to restore some of the biological properties that are lost in AT cells; this might explain why these $\mathrm{T}$ cells have greater expansion and survival rate and are most often observed in AT patients. This assumes even more relevance if we consider that a similar situation of ATM biallelic loss and TCL1 overexpression, other than in AT patients, exists also in several sporadic human cancer types, such as T-PLL, B-CLL and mantle cell lymphoma, suggesting that these two genes cooperate in the development of certain lymphoid tumours.

\section{ACKNOWLEDGEMENTS}

We thank M Proietti for his valuable technical participation in this work. This study was supported by grants from the CNR-MIUR Oncology Project SP/4, Ministero della Sanità 2001 (G Zupi 02/01/ C/4), Telethon Grant D.102 (GR) and Italian Association for Cancer Research.

\section{REFERENCES}

Bebb DG, Warrington PJ, de Jong G, Yu Z, Moffat JA, Skov K, Spacey S, Gelmon K, Glickman BW (2001) Radiation induced apoptosis in ataxia telangiectasia homozygote, heterozygote and normal cells. Mutat Res 476: $13-20$ 
Bichi R, Shinton SA, Martin ES, Koval A, Calin GA, Cesari R, Russo G, Hardy RR, Croce CM (2002) Human chronic lymphocytic leukemia modeled in mouse by targeted TCL1 expression. Proc Natl Acad Sci USA 99: $6955-6960$

Biroccio A, Amodei S, Benassi B, Scarsella M, Cianciulli A, Mottolese M, Del Bufalo D, Leonetti C, Zupi G (2002) Reconstitution of hTERT restores tumorigenicity in melanoma-derived c-Myc low-expressing clones. Oncogene 21: 3011-3019

Blasco MA (2002) Telomerase beyond telomeres. Nat Rev Cancer 2: 627-633

Brennan P, Babbage JW, Burgering BM, Groner B, Reif K, Cantrell DA (1997) Phosphatidylinositol 3-kinase couples the interleukin-2 receptor to the cell cycle regulator E2F. Immunity 7: 679-689

Duchaud E, Ridet A, Stoppa-Lyonnet D, Janin N, Moustacchi E, Rosselli F (1996) Deregulated apoptosis in ataxia telangiectasia: association with clinical stigmata and radiosensitivity. Cancer Res 56: $1400-1404$

Fears S, Chakrabarti SR, Nucifora G, Rowley JD (2002) Differential expression of TCL1 during pre-B-cell acute lymphoblastic leukemia progression. Cancer Genet Cytogenet 135: 110-119

Ferraro C, Quemeneur L, Fournel S, Prigent AF, Revillard JP, BonnefoyBerard N (2000) The topoisomerase inhibitors camptothecin and etoposide induce a CD95-independent apoptosis of activated peripheral lymphocytes. Cell Death Differ 7: 197-206

Gilad S, Khosravi R, Shkedy D, Uziel T, Ziv Y, Savitsky K, Rotman G, Smith S, Chessa L, Jorgensen TJ, Harnik R, Frydman M, Sanal O, Portnoi S, Goldwicz Z, Jaspers NG, Gatti RA, Lenoir G, Lavin MF, Tatsumi K, Wegner RD, Shiloh Y, Bar-Shira A (1996) Predominance of null mutations in ataxia-telangiectasia. Hum Mol Genet 5: 433-439

Greenwell PW, Kronmal SL, Porter SE, Gassenhuber J, Obermaier B, Petes TD (1995) TEL1, a gene involved in controlling telomere length in S. cerevisiae, is homologous to the human ataxia telangiectasia gene. Cell 82: $823-829$

Gritti C, Dastot H, Soulier J, Janin A, Daniel MT, Madani A, Grimber G, Briand P, Sigaux F, Stern MH (1998) Transgenic mice for MTCP1 develop T-cell prolymphocytic leukemia. Blood 92: 368-373

Harley CB, Futcher AB, Greider CW (1990) Telomeres shorten during ageing of human fibroblasts. Nature 345: $458-460$

Hoyer KK, French SW, Turner DE, Nguyen MT, Renard M, Malone CS, Knoetig S, Qi CF, Su TT, Cheroutre H, Wall R, Rawlings DJ, Morse III HC, Teitell MA (2002) Dysregulated TCL1 promotes multiple classes of mature B cell lymphoma. Proc Natl Acad Sci USA 99: 14392 - 14397

Kang SS, Kwon J, Kwon DJ, Do SI (1999) Akt protein kinase enhances human telomerase activity through phosphorylation of telomerase reverse transcriptase subunit. J Biol Chem 274: 13085-13090

Kunstle G, Laine J, Pierron G, Kagami Si S, Nakajima H, Hoh F, Roumestand C, Stern MH, Noguchi M (2002) Identification of Akt association and oligomerization domains of the Akt kinase coactivator TCL1. Mol Cell Biol 22: 1513-1525

Laine J, Kunstle G, Obata T, Sha M, Noguchi M (2000) The protooncogene TCL1 is an Akt kinase coactivator. Mol Cell 6: $395-407$

Lauder A, Castellanos A, Weston K (2001) c-Myb transcription is activated by protein kinase $B$ (PKB) following interleukin 2 stimulation of $T$ cells and is required for PKB-mediated protection from apoptosis. Mol Cell Biol 21: $5797-5805$

Metcalfe JA, Parkhill J, Campbell L, Stacey M, Biggs P, Byrd PJ, Taylor AM (1996) Accelerated telomere shortening in ataxia telangiectasia. Nat Genet 13: $350-353$

Meyn MS (1999) Ataxia-telangiectasia, cancer and the pathobiology of the ATM gene. Clin Genet 55: 289-304
Narducci MG, Pescarmona E, Lazzeri C, Signoretti S, Lavinia AM, Remotti D, Scala E, Baroni CD, Stoppacciaro A, Croce CM, Russo G (2000) Regulation of TCL1 expression in B- and T-cell lymphomas and reactive lymphoid tissues. Cancer Res 60: 2095-2100

Narducci MG, Virgilio L, Isobe M, Stoppacciaro A, Elli R, Fiorilli M, Carbonari M, Antonelli A, Chessa L, Croce CM, Russo G (1995) TCL1 oncogene activation in preleukemic $\mathrm{T}$ cells from a case of ataxiatelangiectasia. Blood 86: $2358-2364$

Nicholson KM, Anderson NG (2002) The protein kinase B/Akt signalling pathway in human malignancy. Cell Signal 14: 381-395

Pandita TK (2002) ATM function and telomere stability. Oncogene 21: 611-618

Pandita TK, Dhar S (2000) Influence of ATM function on interactions between telomeres and nuclear matrix. Radiat Res 154: 133-139

Pandita TK, Pathak S, Geard CR (1995) Chromosome end associations, telomeres and telomerase activity in ataxia telangiectasia cells. Cytogenet Cell Genet 71: 86-93

Pekarsky Y, Hallas C, Isobe M, Russo G, Croce CM (1999) Abnormalities at $14 \mathrm{q} 32.1$ in T cell malignancies involve two oncogenes. Proc Natl Acad Sci USA 96: 2949-2951

Pekarsky Y, Koval A, Hallas C, Bichi R, Tresini M, Malstrom S, Russo G, Tsichlis P, Croce CM (2000) Tcl1 enhances Akt kinase activity and mediates its nuclear translocation. Proc Natl Acad Sci USA 97: $3028-3033$

Petrinelli P, Elli R, Marcucci L, Barbieri C, Ambra R, Antonelli A (1996) VP16 hypersensitivity and increased faulty recombination in ataxia telangiectasia lymphocytes characterized by the tandem translocation $\mathrm{t}(14 ; 14)(\mathrm{q} 11 ; \mathrm{q} 32)$. Carcinogenesis 17: $203-207$

Petrinelli P, Elli R, Marcucci L, Tabolacci E, Barbieri C, Antonelli A (2001) Telomeric associations and chromosome instability in ataxia telangiectasia T cells characterized by TCL1 expression. Cancer Genet Cytogenet 125: $46-51$

Shiloh Y, Kastan MB (2001) ATM: genome stability, neuronal development, and cancer cross paths. Adv Cancer Res 83: 209-254

Sinkule JA (1984) Etoposide: a semisynthetic epipodophyllotoxin. Chemistry, pharmacology, pharmacokinetics, adverse effects and use as an antineoplastic agent. Pharmacotherapy 4: $61-73$

Smith GC, d'Adda di Fagagna F, Lakin ND, Jackson SP (1999) Cleavage and inactivation of ATM during apoptosis. Mol Cell Biol 19: 6076-6084

Stern MH, Soulier J, Rosenzwajg M, Nakahara K, Canki-Klain N, Aurias A, Sigaux F, Kirsch IR (1993) MTCP-1: a novel gene on the human chromosome $\mathrm{Xq} 28$ translocated to the $\mathrm{T}$ cell receptor alpha/delta locus in mature T cell proliferations. Oncogene 8: $2475-2483$

Taylor AM, Metcalfe JA, Thick J, Mak YF (1996) Leukemia and lymphoma in ataxia telangiectasia. Blood 87: 423-438

Virgilio L, Lazzeri C, Bichi R, Nibu K, Narducci MG, Russo G, Rothstein JL, Croce CM (1998) Deregulated expression of TCL1 causes T cell leukemia in mice. Proc Natl Acad Sci USA 95: 3885-3889

Virgilio L, Narducci MG, Isobe M, Billips LG, Cooper MD, Croce CM, Russo G (1994) Identification of the TCL1 gene involved in T-cell malignancies. Proc Natl Acad Sci USA 91: 12530-12534

Wood LD, Halvorsen TL, Dhar S, Baur JA, Pandita RK, Wright WE, Hande MP, Calaf G, Hei TK, Levine F, Shay JW, Wang JJ, Pandita TK (2001) Characterization of ataxia telangiectasia fibroblasts with extended life-span through telomerase expression. Oncogene 20: 278-288

Zhu J, Wang H, Bishop JM, Blackburn EH (1999) Telomerase extends the lifespan of virus-transformed human cells without net telomere lengthening. Proc Natl Acad Sci USA 96: 3723-3728 